\title{
EFEKTIVITAS BAKTERI ENDOFIT SEBAGAI PUPUK HAYATI TERHADAP PERTUMBUHAN DAN PRODUKSI CABAI (Capsicum annuum, L.)
}

\author{
Effectivity of Endophytic Bacteria as Biofertilizer on the Growth and \\ Chilli Production (Capsicum annuum L.)
}

\section{Rahmi Zuhra* Hasanuddin, Lisnawita}

Program Studi Magister Agroekoteknologi, Fakultas Pertanian USU, Medan 20155

*Coresponding author: rahmizuhra@yahoo.co.id

\begin{abstract}
The endophytic bacteria is one of the microbes that can be used as biofertilizer to enhance the growth and production of chili. The aim of research to determine the effectivity of endophytic bacteria as biofertilizer origin of chili and corn to increase the growth and production of chili. The experiment was conducted at home of gauze, Langsa Aceh. The research method is a randomized block design with 19 treatment and 3 replication. The results showed that isolates A1 (from roots chilli) and A20 (from the roots of corn) were effective against root growth, while the A24 isolates (from corn stalks) are effective against plant height and chili.
\end{abstract}

Keywords : endophytic bacterial, biofertilizer. corn, growth, production

\begin{abstract}
ABSTRAK
Bakteri endofit merupakan salah satu mikroba yang dapat digunakan untuk meningkatkan pertumbuhan dan produksi cabai. Tujuan penelitian untuk mengetahui efektivitas dari bakteri endofit sebagai pupuk hayati asal cabai dan jagung untuk meningkatkan pertumbuhan dan produksi cabai. Penelitian dilaksanakan di rumah kassa, di Langsa Aceh. Metode penelitian yang dilakukan adalah rancangan acak kelompok dengan 19 perlakuan dan 3 ulangan. Hasil penelitian menunjukkan bahwa isolat A1 (dari akar cabai) dan A20 (dari akar jagung) efektif terhadap pertumbuhan akar, sedangkan isolat A24 (dari batang jagung) efektif terhadap tinggi tanaman dan produksi cabai.
\end{abstract}

Kata kunci : Bakteri endofit, pupuk hayati. jagung, pertumbuhan, produksi 


\section{PENDAHULUAN}

Cabai (Capsicum annuum, L.) merupakan salah satu komoditas sayuran penting dan bernilai ekonomi tinggi di Indonesia. Tanaman cabai dikembangkan baik di dataran rendah maupun dataran tinggi (Syukur et al., 2013). Buah cabai banyak digunakan oleh masyarakat sebagai rempah dan bumbu masakan. Seiring dengan pertambahan penduduk yang pesat dan berkembangnya industri makanan, maka kebutuhan cabai di Indonesia meningkat (Soelaiman \& Ernawati, 2013).

Cabai mengandung zat-zat gizi yang sangat penting untuk kesehatan manusia seperti protein, lemak, karbohidrat, kalsium, fosfor, besi, vitamin $\mathrm{C}, \mathrm{A}$ dan $\mathrm{E}$ serta senyawa-senyawa alkaloid seperti capsaicin, flavonoid dan minyak esensial. Senyawa capsaicin yang terkandung di dalam buah cabai menyebabkan rasa pedas dan juga berfungsi melancarkan sirkulasi peredaran darah (Prayudi, 2010).

Menurut Badan Pusat Statistik (2014), luas area panen cabai di Indonesia pada tahun 2013 sebesar 13,46 ribu hektar, namun luas area panen tersebut tidak didukung dengan nilai produktivitas yang tinggi, di Jawa Timur hanya mencapai 7,56 ton/ha. Kondisi ini masih jauh dari produktivitas potensial cabai yang mampu berproduksi hingga mencapai 20-30 ton/ha (Rosidah et al., 2014). Berdasarkan hal tersebut, maka usaha peningkatan produksi cabai dapat dilakukan dengan cara perbaikan teknik budidaya yang meliputi pemupukan dengan pupuk organik, pupuk hayati dan penggunaan varietas cabai yang sesuai (Nurahmi et al., 2011)

Penggunaan pupuk anorganik pada lahan pertanian dalam jangka panjang dapat mengganggu keseimbangan ekosistem dan menurunkan jumlah mikroflora tanah (Tian et al., 2004). Pupuk hayati adalah salah satu alternatif teknologi ramah lingkungan yang bisa menggantikan penggunaan pupuk sintetis karena sifatnya lebih ramah lingkungan. Bakteri endofit merupakan kandidat yang potensial dikembangkan menjadi pupuk hayati (Bintang \& Dewi, 2013).

Hallman dan Berg (2006) menyebutkan bahwa keunggulan bakteri endofit sebagai agens hayati, mampu meningkatkan pertumbuhan tanaman yang dikenal dengan Plant Growth Promoting Rhizobakteria (PGPR), karena dapat meningkatkan ketersediaan nutrisi, menghasilkan hormon pertumbuhan serta menginduksi ketahanan tanaman yang dikenal dengan Induced Systemic Resistance (ISR). Bakteri endofit dapat diperoleh dari semua tanaman dan berbagai jaringan. Setiap tanaman dapat menghasilkan lebih dari satu bakteri endofit yang berpotensi sebagai agens hayati.

Sampai saat ini sedikit sekali informasi tentang potensi bakteri endofit asal tanaman cabai dan jagung. Menurut Khairani (2009), bakteri endofit dari akar jagung mengandung zat perangsang tumbuh (IAA). Selanjutnya hasil penelitian Munif et al. (2012), bahwa perlakuan benih tomat dengan bakteri endofit dapat meningkatkan bobot basah akar dan panjang akar tanaman tomat. Harni dan Ibrahim (2011) menyatakan bahwa perendaman akar bibit lada dengan beberapa isolat bakteri endofit yang diisolasi dari tanaman lada juga dapat meningkatkan bobot akar dan bobot tajuk tanaman lada. Peran bakteri endofit diketahui cukup signifikan dalam meningkatkan produksi padi (Govindarajan et al., 2008), hal ini diharapkan juga dapat dimanfaatkan pada tanaman cabai

Dari uraian di atas peneliti tertarik untuk melakukan penelitian tentang efektivitas bakteri endofit yang diisolasi dari beberapa jaringan tanaman cabai dan jagung untuk meningkatkan pertumbuhan dan produksi cabai dengan tujuan untuk mendapatkan bakteri endofit yang efektif sebagai pupuk hayati dari isolat tanaman 
cabai dan jagung dalam meningkatkan pertumbuhan dan produksi cabai.

\section{BAHAN DAN METODA}

Penelitian ini dilaksanakan di
rumah kassa di Langsa Aceh, dilaksanakan pada bulan Januari sampai September 2014. Penelitian ini menggunakan metode Rancangan Acak Kelompok (RAK) non Faktorial terdiri dari 19 perlakuan dan 3 ulangan, yaitu : $\mathrm{A} 0=$ Kontrol, $\mathrm{A} 1=$ Isolat bakteri dari akar cabai (CA1NA), A5 = Isolat bakteri dari akar cabai (CA5NA), A7 = Isolat bakteri dari akar cabai $(\mathrm{CA} 7 \mathrm{~KB}), \mathrm{A} 8=$ Isolat bakteri dari daun cabai (CD1NA), A9 = Isolat bakteri dari daun cabai $(\mathrm{CD} 2 \mathrm{NA}), \mathrm{A} 10=$ Isolat bakteri dari daun cabai $(\mathrm{CD} 3 \mathrm{NA}) \mathrm{A} 11=$ Isolat bakteri dari daun cabai $(\mathrm{CD} 4 \mathrm{~KB}), \mathrm{A} 12$ = Isolat bakteri dari daun cabai $(\mathrm{CD} 5 \mathrm{~KB}), \mathrm{A} 14=$ Isolat bakteri dari batang cabai (CB1NA), A15 = Isolat bakteri dari batang cabai (CB2NA), A17 = Isolat bakteri dari akar jagung (JA1NA), A18 = Isolat bakteri dari akar jagung (JA2NA), A19 = Isolat bakteri dari akar jagung (JA3NA), A20 = Isolat bakteri dari akar jagung (JA4KB), A24 = Isolat bakteri dari batang jagung (JB3KB), A26 = Isolat bakteri dari daun jagung (JD1NA), A27 = Isolat bakteri dari daun jagung (JD2NA), A28 = Isolat bakteri dari daun jagung (JD3KB).

Data dianalisis dengan menggunakan analisis sidik ragam. Apabila terdapat pengaruh nyata, maka dilanjutkan dengan Uji Jarak Berganda Duncan (UJBD) pada taraf kepercayaan $0,05 \%$.

\section{Pelaksanaan Penelitian}

Lahan dibersihkan dari rumput dan segala kotoran lainnya. Selanjutnya dibuat rumah kasa menghadap ke Timur yang berukuran: $11 \times 6,2 \times 3 \mathrm{~m}$. Atap rumah kasa terbuat dari plastik yang tembus cahaya, sedangkan di sekelilingnya ditutupi dengan kain kasa yang halus, guna mencegah masuknya serangga dan hama lainnya.

Persemaian benih dilakukan dalam polibeg kecil dengan ukuran $4 \times 6 \mathrm{~cm}$, yang berisi media tanah dengan pupuk kandang 1:1 dan disterilkan. Setelah itu media tanam dibiarkan 5-7 hari sebelum benih disemai, dengan meletakkannya di atas rak dengan ketinggian 1 meter dari lantai di dalam rumah kassa.

18 isolat bakteri endofit hasil eksplorasi sebelumnya dibiakkan pada media NA dan Kings B. Setelah bakteri berumur 1x24 jam ditambahkan $10 \mathrm{ml}$ air steril, lalu dimasukkan ke beaker glass/erlemayer steril. Selanjutkan dilakukan pengenceran bertingkat hingga $10^{-5}$ cfu. Setelah itu benih cabai dimasukkan ke dalam larutan bakteri selama 30-60 menit sambil diguncang dengan shaker dengan kecepatan $100 \mathrm{rpm}$, dan siap disemai (Hartini, 2004).

Benih disemai dalam polibeg kecil sebanyak 5 benih/polibeg. Setiap perlakuan disemai sebanyak 12 polibeg untuk persiapan penyulaman. Penyiraman dilakukan setiap hari pagi atau sore hari, guna menjaga kelembaban media. Persemaian benih dilakukan selama 2130 hari. Setelah bibit memiliki 3 sampai 4 helai daun bibit siap dipindahkan ke polibeg besar.

Polibeg disiapkan untuk penanaman bibit, yang berlubang kiri kanannya untuk pengaturan air. Media tanam berupa campuran tanah, pupuk kandang dan pasir 2:1:0,5 diisi ke dalam polibeg kapasitas $5 \mathrm{~kg}$ sebanyak $2 / 3$ bagian. Polibeg diatur sesuai perlakuan dengan jarak $60 \times 40 \mathrm{~cm}$. Setiap plot terdiri dari 3 tanaman yang semuanya digunakan sebagai tanaman sampel.

Penanaman dilakukan pada bibit cabai yang berumur 30 hari. Setiap polibeg berisi 1 bibit. Setelah tanaman berumur 2 minggu pada setiap tanaman diberi ajir untuk menopang pertumbuhan tanaman. Penyiraman dilakukan setiap pagi dan sore hari. 
Pemupukan dilakukan 1 hari setelah tanaman dipindahkan ke polibeg besar, yaitu dengan pemberian pupuk kandang sapi 100 g/tanaman. Selanjutkan pemupukan susulan dilakukan tiap 2 minggu sekali dengan dosis 100 g/tanaman yang sama sampai panen pertama (Nurliana, 2012).

Penyulaman dilakukan bila ada bibit muda yang rusak ataupun mati, dilakukan pada saat umur tanaman 1-2 minggu setelah penanaman/pemindahan bibit ke polibeg besar.

Untuk pengendalian hama digunakan pestisida organik dengan menggunakan 100 lembar daun sirsat diblender lalu ditambahkan $30 \mathrm{~g}$ sabun colek, aduk rata sambil tambahkan air hingga 5 liter, saring dan disemprotkan ke seluruh tanaman cabai. Penyiangan gulma dilakukan sekali seminggu, dengan membersihkan gulma yang tumbuh di sekitar tanaman.

Cabai merah dipanen umur 110 hari setelah tanam, pemanenan dilakukan dengan interval 5 hari sebanyak 8 kali.

\section{Peubah Amatan}

Pengukuran tinggi tanaman dilakukan dengan mengukur tanaman dari permukaan tanah sampai dengan titik tumbuh tertinggi. Pengukuran dilakukan mulai umur 1, 3, 5, 7 dan 9 MST.

Produksi dihitung dengan menimbang buah cabai setiap plot perlakuan dan ditimbang tiap-tiap panen dengan kriteria cabai telah berwarna merah merata sampai dengan panen ke-8, kemudian semua produksi ditotal lalu dikonversikan dalam ton/ha.

Ton $/$ ha $=\frac{\text { Jumlah tan } / \text { Ha }}{\text { Jumlah tan } / \text { plot }} \times$ Produksi/plot $(\mathrm{kg})$

Panjang akar diukur setelah tanaman cabai dipanen. Tanaman dicabut hati-hati agar tidak ada akar yang putus, pengukuran dimulai dari pangkal batang sampai dengan ujung akar yang terpanjang.
Berat segar akar diamati pada saat panen terakhir, dengan cara memotong tanaman cabai pada batas pangkal batang, lalu ditimbang dengan menggunakan timbangan. Akar dicuci bersih sebelum ditimbang (Fahrudin, 2009).

Berat kering akar dihitung dengan memasukkan akar ke dalam amplop, setelah itu dikeringkan dalam oven dengan suhu $60^{\circ} \mathrm{C}$ selama $5 \times 24$ jam.

\section{HASIL DAN PEMBAHASAN}

\section{Tinggi tanaman $(\mathrm{cm})$}

Perlakuan bakteri endofit berpengaruh sangat nyata terhadap tinggi tanaman cabai pada umur 1, 3, 5, 7 dan 9 MST. Rata-rata tinggi tanaman cabai akibat perlakuan bakteri endofit dapat dilihat pada Tabel 1.

Isolat A24 dan A26 menunjukkan pengaruh yang nyata terhadap tinggi tanaman cabai umur 1, 3, 5 dan 7 MST. Data tinggi tanaman cabai akibat perlakuan isolat A24 dan A26 adalah $(9,24 \mathrm{~cm} ; 8,96 \mathrm{~cm}),(11,57 \mathrm{~cm} ; 11,93 \mathrm{~cm})$, $(16,99 \mathrm{~cm} ; 16,18 \mathrm{~cm})$ dan $(23,48 \mathrm{~cm}$; $23,30 \mathrm{~cm}$ ), sedangkan pada umur 9 MST isolat A7 menunjukkan pengaruh yang nyata terhadap tinggi tanaman cabai, tetapi berbeda tidak nyata dengan perlakuan A14, A24, A26 dan A0.

Hasil uji beda rerata DMRT pada Tabel 7 menunjukkan bahwa dari 18 isolat yang diuji diperoleh 6 isolat yaitu A7, A9, A14, A24, A26, A27 yang dapat memacu tinggi tanaman cabai umur 1, 3, 5, 7 dan 9 MST dibanding kontrol. Diduga isolat tersebut memiliki kemampuan menghasilkan hormon seperti auxin dan sitokinin, sehingga mampu meningkatkan pertumbuhan tanaman serta ketersediaan unsur hara, hal ini sesuai pendapat Bacon \& Hinton (2007), bakteri endofit dapat meningkatkan pertumbuhan tanaman dengan cara meningkatkan ketersediaan nutrisi tanaman seperti nitrogen, fosfat, dan mineral lainnya, serta merangsang pertumbuhan tanaman dengan menghasilkan hormon 
pertumbuhan seperti etilen, auksin, dan sitokinin. Hasil penelitian lain juga melaporkan beberapa bakteri endofit dapat berasosiasi dan memacu pertumbuhan cabai (Sundaramoorthy et $a l, .2012)$.

Hormon tanaman mengatur beberapa aspek pertumbuhan dan perkembangan tanaman, seperti pembentukan dan pemeliharaan meristem (Su et al., 2011). Pemberian hormon secara eksogen yang umum dilakukan sama pengaruhnya terhadap respon sel tanaman dengan hormon endogenus yang disintesis oleh bakteri (Yamada, 1993). Hormon berperan mempercepat pertumbuhan dan perkembangan tanaman. Adanya hormon yang diproduksi oleh bakteri endofit tersebut diduga membantu memacu pertumbuhan tanaman cabai.

Peningkatan serapan hara tersebut juga dapat diakibatkan karena bakteri endofit yang digunakan mampu memproduksi hormon GA3. Hormon tersebut mampu memacu serapan hara $\mathrm{N}$, $\mathrm{P}$, dan K. Hormon GA3 mengatur pertumbuhan tanaman melalui peningkatan pemanjangan sel (Eid dan Laila, 2006).

Selain itu bakteri yang mendukung pertumbuhan tanaman secara tidak langsung memproduksi senyawa antagonis berupa siderofor atau menginduksi sistem pertahanan tanaman terhadap patogen (Diniyah, 2010).

\section{Panjang Akar, Berat Basah dan Berat Kering Akar}

Perlakuan isolat bakteri endofit berpengaruh sangat nyata terhadap panjang, berat basah dan kering akar tanaman cabai. Dari Tabel 2. rataan panjang akar bahwa panjang akar tertinggi terdapat pada perlakuan

Tabel 1. Rerataan tinggi tanaman cabai akibat perlakuan isolat bakteri endofit

\begin{tabular}{cllllll}
\hline \multirow{2}{*}{ Perlakuan } & \multirow{2}{*}{ Kode Isolat } & \multicolumn{5}{c}{ Tinggi tanaman $(\mathrm{cm})$} \\
\cline { 3 - 7 } & & $1 \mathrm{MST}$ & \multicolumn{1}{c}{$3 \mathrm{MST}$} & \multicolumn{1}{c}{$5 \mathrm{MST}$} & $7 \mathrm{MST}$ & $9 \mathrm{MST}$ \\
\hline A0 & Kontrol & $7.32 \mathrm{ef}$ & $9.9 \mathrm{efg}$ & $14.12 \mathrm{ef}$ & $21.79 \mathrm{ef}$ & $29.23 \mathrm{ef}$ \\
A1 & CA1NA & $5.74 \mathrm{abcd}$ & $9.28 \mathrm{def}$ & $12.83 \mathrm{def}$ & $18.29 \mathrm{bcd}$ & $25.10 \mathrm{bcd}$ \\
A5 & CA5NA & $5.91 \mathrm{bcd}$ & $9.09 \mathrm{cde}$ & $11.84 \mathrm{~cd}$ & $16.41 \mathrm{ab}$ & $20.72 \mathrm{a}$ \\
A7 & CA7KB & $5.33 \mathrm{abc}$ & $7.93 \mathrm{abcd}$ & $13.98 \mathrm{ef}$ & $20.43 \mathrm{de}$ & $32.51 \mathrm{f}$ \\
A8 & CD1NA & $4.64 \mathrm{a}$ & $8.16 \mathrm{abcd}$ & $11.04 \mathrm{ab}$ & $16.73 \mathrm{ab}$ & $23.99 \mathrm{abc}$ \\
A9 & CD2NA & $6.04 \mathrm{bcd}$ & $8.79 \mathrm{bcde}$ & $13.36 \mathrm{ef}$ & $22.04 \mathrm{efg}$ & $27.82 \mathrm{cde}$ \\
A10 & CD3NA & $5.10 \mathrm{ab}$ & $6.98 \mathrm{a}$ & $12.07 \mathrm{~cd}$ & $19.43 \mathrm{~cd}$ & $26.22 \mathrm{~cd}$ \\
A11 & CD4KB & $6.96 \mathrm{def}$ & $9.51 \mathrm{ef}$ & $14.18 \mathrm{efg}$ & $20.82 \mathrm{def}$ & $27.27 \mathrm{~cd}$ \\
A12 & CD5KB & $6.09 \mathrm{bcde}$ & $7.96 \mathrm{abcd}$ & $11.07 \mathrm{abc}$ & $17.18 \mathrm{abc}$ & $22.89 \mathrm{ab}$ \\
A14 & CB1NA & $5.51 \mathrm{abc}$ & $7.59 \mathrm{ab}$ & $12.51 \mathrm{cde}$ & $20.49 \mathrm{de}$ & $28.54 \mathrm{def}$ \\
A15 & CB2NA & $5.50 \mathrm{abc}$ & $8.13 \mathrm{abcd}$ & $12.69 \mathrm{cde}$ & $19.18 \mathrm{~cd}$ & $22.88 \mathrm{~cd}$ \\
A17 & JA1NA & $5.00 \mathrm{abc}$ & $7.53 \mathrm{ab}$ & $9.94 \mathrm{ab}$ & $15.88 \mathrm{ab}$ & $22.86 \mathrm{ab}$ \\
A18 & JA2NA & $5.52 \mathrm{abc}$ & $7.69 \mathrm{abc}$ & $11.02 \mathrm{ab}$ & $18.86 \mathrm{~cd}$ & $26.40 \mathrm{~cd}$ \\
A19 & JA3NA & $5.11 \mathrm{ab}$ & $7.12 \mathrm{a}$ & $9.58 \mathrm{a}$ & $14.82 \mathrm{a}$ & $21.14 \mathrm{ab}$ \\
A20 & JA4KB & $6.48 \mathrm{cde}$ & $8.53 \mathrm{bcde}$ & $11.46 \mathrm{bcd}$ & $17.87 \mathrm{bc}$ & $23.62 \mathrm{ab}$ \\
A24 & JB3KB & $9.24 \mathrm{~h}$ & $11.57 \mathrm{gh}$ & $16.99 \mathrm{~h}$ & $23.48 \mathrm{~g}$ & $29.77 \mathrm{ef}$ \\
A26 & JD1NA & $8.96 \mathrm{gh}$ & $11.93 \mathrm{~h}$ & $16.18 \mathrm{gh}$ & $23.30 \mathrm{fg}$ & $29.94 \mathrm{ef}$ \\
A27 & JD2NA & $7.87 \mathrm{fg}$ & $10.62 \mathrm{fgh}$ & $15.50 \mathrm{fgh}$ & $22.63 \mathrm{fg}$ & $28.49 \mathrm{de}$ \\
A28 & JD3KB & $5.68 \mathrm{abc}$ & $8.91 \mathrm{bcde}$ & $12.10 \mathrm{~cd}$ & $19.61 \mathrm{cde}$ & $22.62 \mathrm{ab}$ \\
\hline
\end{tabular}

Keterangan: Angka diikuti oleh huruf yang sama pada lajur yang sama berbeda tidak nyata pada Uji DMRT taraf 0,05 . 
isolat A20 yang berasal dari akar jagung, berbeda nyata dengan A0, A1, A7, A8, A9, A10, A11, A12, A14, A17, A18, A19, A24, A27 dan A28, tetapi berbeda tidak nyata dengan perlakuan A26, A15 dan A5. Selanjutnya rataan berat basah akar berasal dari perlakuan isolat A1 berbeda nyata dengan A5, A7, A8, A9, A10, A12, A14, A17, A19 dan A24, namun berbeda tidak nyata dengan $\mathrm{A} 0$, A11, A15, A18, A20, A26, A27 dan A28.

Rataan berat kering akar tertinggi diperoleh pada perlakuan isolat A1 (dari akar cabai) dan berat kering akar terendah pada perlakuan A8 asal daun cabai. Perlakuan isolat A1 berbeda nyata dengan A0, A5, A7, A8, A9, A10, A12, A14, A17, A18, A19, A20, A24, A26 dan A27, tetapi berbeda tidak nyata dengan A11, A15 dan A28. Dari rataan panjang akar, berat basah dan berat kering akar, secara keseluruhan perlakuan isolat terbaik A1, A5, A11, A15, A18, A20, A26, A27 dan A28 sebagai pemacu pertumbuhan pada tanaman cabai. Hal ini diduga isolat bakteri endofit mangandung hormon pertumbuhan yang dapat merangsang pertumbuhan akar.

Hasil penelitian yang dilakukan oleh Gusmaini et al. (2013) diperoleh bahwa hormon pertumbuhan tanaman, selain diproduksi sendiri oleh tanaman dapat pula diperoleh dari bakteri endofit. Sejalan dengan produksi hormon yang dihasilkan oleh bakteri endofit, pertumbuhan tanaman juga meningkat. Peningkatan pertumbuhan tanaman baik tinggi tanaman maupun jumlah daun berkolerasi positif dengan sumbangan hormon yang dihasilkan oleh isolat bakteri endofit. Semua isolat memproduksi hormon IAA dan GA3 dan memberikan pertumbuhan tanaman lebih

Tabel 2. Rerataan panjang akar, berat basah akar dan berat kering akar akibat perlakuan isolat bakteri endofit

\begin{tabular}{cllcl}
\hline Perlakuan & Kode Isolat & $\begin{array}{c}\text { Panjang } \\
\text { akar }(\mathrm{cm})\end{array}$ & $\begin{array}{c}\text { Berat basah akar } \\
(\mathrm{g})\end{array}$ & $\begin{array}{c}\text { Berat kering akar } \\
(\mathrm{g})\end{array}$ \\
\hline A0 & Kontrol & $25.57 \mathrm{a}$ & $7.91 \mathrm{bcd}$ & $4.72 \mathrm{bc}$ \\
A1 & CA1NA & $26.78 \mathrm{abc}$ & $9.56 \mathrm{~d}$ & $6.01 \mathrm{~d}$ \\
A5 & CA5NA & $29.94 \mathrm{cde}$ & $7.17 \mathrm{bc}$ & $4.48 \mathrm{abc}$ \\
A7 & CA7KB & $26.33 \mathrm{ab}$ & $6.36 \mathrm{abc}$ & $3.92 \mathrm{a}$ \\
A8 & CD1NA & $24.30 \mathrm{a}$ & $5.99 \mathrm{ab}$ & $3.44 \mathrm{a}$ \\
A9 & CD2NA & $25.51 \mathrm{ab}$ & $7.74 \mathrm{bc}$ & $4.22 \mathrm{ab}$ \\
A10 & CD3NA & $29.66 \mathrm{~cd}$ & $7.06 \mathrm{bc}$ & $4.39 \mathrm{ab}$ \\
A11 & CD4KB & $25.88 \mathrm{ab}$ & $8.99 \mathrm{~d}$ & $5.34 \mathrm{~cd}$ \\
A12 & CD5KB & $27.18 \mathrm{abc}$ & $7.39 \mathrm{bc}$ & $5.59 \mathrm{a}$ \\
A14 & CB1NA & $28.02 \mathrm{bcd}$ & $6.10 \mathrm{ab}$ & $3.54 \mathrm{a}$ \\
A15 & CB2NA & $30.26 \mathrm{de}$ & $9.31 \mathrm{~d}$ & $5.20 \mathrm{~cd}$ \\
A17 & JA1NA & $26.34 \mathrm{ab}$ & $4.42 \mathrm{a}$ & $4.47 \mathrm{ab}$ \\
A18 & JA2NA & $29.27 \mathrm{~cd}$ & $7.79 \mathrm{bcd}$ & $4.32 \mathrm{ab}$ \\
A19 & JA3NA & $24.66 \mathrm{a}$ & $7.52 \mathrm{bc}$ & $3.51 \mathrm{a}$ \\
A20 & JA4KB & $33.00 \mathrm{e}$ & $8.29 \mathrm{~cd}$ & $4.41 \mathrm{ab}$ \\
A24 & JB3KB & $26.02 \mathrm{ab}$ & $7.46 \mathrm{bc}$ & $3.97 \mathrm{ab}$ \\
A26 & JD1NA & $30.43 \mathrm{de}$ & $8.63 \mathrm{~d}$ & $4.51 \mathrm{ab}$ \\
A27 & JD2NA & $27,56 \mathrm{bc}$ & $8.52 \mathrm{~cd}$ & $4.32 \mathrm{ab}$ \\
A28 & JD3KB & $28.61 \mathrm{bcd}$ & $8.29 \mathrm{~cd}$ & $5.04 \mathrm{bcd}$ \\
\hline
\end{tabular}

Keterangan : Angka diikuti oleh huruf yang sama pada lajur yang sama berbeda tidak nyata pada uji DMRT taraf 0,05

baik dibanding tanpa pemberian isolat

bakteri, Hal ini sesuai penelitian Eliza
(2004) bahwa bakteri endofit yang diisolasi dari perakaran jagung dapat 
merangsang pertumbuhan akar lateral, akar adventif, akar primer dan menghasilkan hormon pertumbuhan sehingga tanaman dapat tumbuh lebih baik. Perpanjangan akar akan mendorong berat basah dan kering akar meningkat, yang mengakibatkan pertumbuhan tanaman menjadi lebih baik, dan akhirnya sampai kepada hasil yang meningkat. Hal tersebut disebabkan bakteri endofit yang diisolasi dari akar tanaman jagung dapat menghasilkan hormon IAA (indole-3acetic acid) (Khairani, 2009).

Selanjutnya penelitian Sutariati (2006), bakteri Bacillus sp. dan Pseudomonas sp. yang berhasil diisolasi dari perakaran jagung dan cabai mempunyai kemampuan sebagai bakteri antagonis, penghasil hormon pertumbuhan, pelarut phospat, penambat nitrogen, sekresi enzim (kitinase, protease, selulose), memproduksi hidrogen sianida $(\mathrm{HCN})$.

\section{Hasil (ton/ha)}

Hasil analisis sidik ragam menunjukkan bahwa perlakuan benih dengan isolat bakteri endofit berpengaruh sangat nyata terhadap hasil panen cabai. Rata-rata hasil panen tanaman akibat perlakuan isolat bakteri endofit dapat dilihat pada Tabel 3

Tabel 3 menunjukkan bahwa panen yang lebih tinggi terdapat pada perlakuan isolat A24 (dari batang jagung), A20 (akar jagung), A26 (daun jagung), A11 (daun cabai) dan A8 (daun cabai), yang berbeda nyata dengan A0, A1, A5, A7, A12, A14, A17, A18, A19, A27 dan A28, tetapi berbeda tidak nyata dengan A9, A10 dan A15.

Rata-rata produksi tertinggi terdapat pada perlakuan isolat A24 yang berasal dari batang jagung. Hal ini diduga bakteri endofit mampu memproduksi hormon pertumbuhan dan membantu tersedianya unsur hara, sehingga dapat mempengaruhi produksi.
Tabel 3. Rerataan produksi cabai akibat perlakuan isolat bakteri endofit

\begin{tabular}{ccc}
\hline Perlakuan & $\begin{array}{c}\text { Kode } \\
\text { Isolat }\end{array}$ & $\begin{array}{c}\text { Produksi } \\
\text { Ton/ha }\end{array}$ \\
\hline A0 & Kontrol & $11.77 \mathrm{ab}$ \\
A1 & CA1NA & $12.14 \mathrm{abc}$ \\
A5 & CA5NA & $13.66 \mathrm{~cd}$ \\
A7 & CA7KB & $13.11 \mathrm{bc}$ \\
A8 & CD1NA & $15.64 \mathrm{e}$ \\
A9 & CD2NA & $14.18 \mathrm{cde}$ \\
A10 & CD3NA & $14.82 \mathrm{de}$ \\
A11 & CD4KB & $15.75 \mathrm{e}$ \\
A12 & CD5KB & $10.76 \mathrm{a}$ \\
A14 & CB1NA & $13.56 \mathrm{~cd}$ \\
A15 & CB2NA & $14.52 \mathrm{de}$ \\
A17 & JA1NA & $12.85 \mathrm{bc}$ \\
A18 & JA2NA & $13.88 \mathrm{~cd}$ \\
A19 & JA3NA & $13.94 \mathrm{~cd}$ \\
A20 & JA4KB & $16.10 \mathrm{e}$ \\
A24 & JB3KB & $16.28 \mathrm{e}$ \\
A26 & JD1NA & $15.63 \mathrm{e}$ \\
A27 & JD2NA & $13.24 \mathrm{~cd}$ \\
A28 & JD3KB & $12.64 \mathrm{bc}$ \\
\hline Ke
\end{tabular}

Keterangan: Angka diikuti oleh huruf yang sama pada lajur yang sama berbeda tidak nyata pada uji DMRT taraf 0,05.

Selain itu adanya akumulasi nutrien seperti nitrogen, fosfat dan senyawa lainnya yang dihasilkan oleh bakteri endofit. Peningkatan kandungan nitrogen dapat berpengaruh terhadap fotosintesis, sehingga meningkatkan fotosintat yang dapat berpengaruh terhadap pembentukan buah cabai, didukung pendapat Soedradjad \& Avivi (2005) bahwa peningkatan laju fotosintesis akan meningkatkan fotosintat tanaman yang dapat meningkatkan produksi tanaman. Selain itu fosfat merupakan unsur mikro penting yang dibutuhkan tanaman untuk pertumbuhan dan perkembangannya. Beberapa bakteri endofit dapat melarutkan fosfat menjadi tersedia dan mudah diserap tanaman, hal ini sesuai pendapat Thakuria et al. (2004) bahwa bakteri pelarut fosfat dapat meningkatkan produksi padi 5,4\%$21,6 \%$.

Selain itu Pujisiswanto dan Pangaribuan (2008), mengatakan bahwa 
pertumbuhan tanaman adalah penimbunan bahan kering tanaman per satuan luas per satuan waktu. Bahan kering tanaman merupakan gambaran dari tranlokasi hasil fotosintesis (fotosintat) ke seluruh bagian tanaman sehingga dapat dikatakan laju tumbuh tanaman sangat ditentukan oleh luas daun tanaman yang mampu mengintersepsi sinar matahari langsung secara maksimum dan laju fotosintesis tanaman selanjutnya.

Gusmaini et al. (2013) melaporkan bahwa pemberian bakteri endofit mampu meningkatkan serapan hara N, P dan K. Peningkatan tersebut sejalan dengan produksi bahan kering tanaman. Serapan hara tanaman dipengaruhi oleh kadar hara yang terkandung di dalam tanaman dan produksi bahan kering tanaman tersebut. Pemberian bakteri endofit mampu meningkatkan bahan kering tanaman.

\section{SIMPULAN}

Isolat A1 (dari akar cabai) dan A20 (dari akar jagung) efektif terhadap pertumbuhan akar, sedangkan isolat A24 (dari batang jagung) efektif terhadap tinggi tanaman dan produksi cabai.

\section{DAFTAR PUSTAKA}

Bacon CW \& Hinton SS. 2007. Bacterial Endophytes: The Endophytic Nische, its Occupants, and its Utility. In: Gnanamanickam SS. Gnanamanickam (ed.). PlantAssociated Bacteria. Springer, Berlin. pp. 155-194.

Badan Pusat Statistik. 2014. Produksi Cabai Besar, Cabai Rawit dan Bawang Merah Angka Tetap (Atap) Tahun 2013. Berita Resmi Statistik Provinsi Jawa Timur, 56(12): 1-8
Bintang M \& Dewi EK, 3013. Pupuk Hayati Berbasis Bakteri Endofit .Departemen Biokimia, FMIPA. Institut Pertanian Bogor. Prociding Seminar ISBN 978-602-19421-09.

Brock TD \& Madigan MT. 1988. Biology of Microorganism. Prentice-Hall International Edition.

Diniyah S. 2010. Potensi Isolat Bakteri Endofit sebagai Penghambat Pertumbuhan Bakteri (Ralstonia solanacearum) dan Jamur (Fusariumsp) dan (Phytophthora infestans) Penyebab Penyakit Layu pada Tanaman. [Skripsi]. Universitas Islam Negeri Malang (UIN). Malang. (Publikasi)

Eid RA, \& Laila BHA. 2006. Response of Croton Plants to Gibbberellic Acid, Benzyl Adenine and Ascorbic Acid Application. World J Agr. Sci. 2(2): 174-179.

Eliza. 2004. Pengendalian Layu Fusarium pada Pisang dengan Bakteri Perakaran Graminae. [Tesis]. Institut Pertanian Bogor.

Fahrudin F. 2009. Budidaya Caisim (Brassica juncea, L.) Menggunakan Ekstrak Teh dan Pupuk Cascing. Fakultas Pertanian Universitas Sebelas Maret Surakarta.

Govindarajan M, Balandreau J, Kwon SW, Weon HY dan Lakshminarasimhan, 2008.Effect of the inoculation of Burkhkolderia vietnamensis and related endophytic diazotropik bacteria on grain yield of rice. Mikrob.Ecol.55(1)21-27.

Gusmaini, Aziz SA, Munif A, Sopandi D \& Bermawi N. 2013. Potensi Bakteri Endofit dalam Upaya Meningkatkan Pertumbuhan, Produksi dan Kandungan 
Andrografolid pada Tanaman Sambiloto. J Littri 19(4): 167 - 177

Hallman \& G. Berg. 2006. Spectrum and Population Dynamics of Bacterial Root Endophytes.

Harni R \& Ibrahim MSD. 2011. Potensi Bakteri Endofit Menginduksi Ketahanan Tanaman Lada terhadap Infeksi Meloidogyne incognita. Balai Penelitian Tanaman Rempah dan Aneka Tanaman Industri. J Littri 17 : 118 $-123$

Hartini A. 2004. Isolasi Bakteri Endofit dan Pengujian untuk Mengendalikan Nematoda Meloigogyne spp. pada Tomat (Lycopersicon enculentum Mill.) [Skripsi]. Departemen Hama dan Penyakit Tumbuhan Fakultas Pertanian Institut Pertanian Bogor.

Khairani G. 2009. Isolasi dan Uji Kemampuan Bakteri Endofit Penghasil Hormon IAA (Indole Acetic Acid) dari Akar Tanaman Jagung. [Skripsi]. Departemen Biologi Fakultas Matematika dan Ilmu Pengetahuan Alam Unversitas Sumatra Utara Medan.

Munif A, Wiyono S, Suwarno. 2012. Isolasi Bakteri Endofit Asal Padi Gogo dan Potensinya sebagai Agens Biokontrol dan Pemacu Pertumbuhan. J Fitopatol Indones. 8(3):57-64.

Nurahmi E, Mahmud T \& Sylvia RS. 2011. Efektivitas Pupuk Organik terhadap Cabai J. Floratek vol $6: 2$ ISSN 1907-2689

Nurliana 2012. Uji Efektifitas Aplikasi Bakteri Antagonis Pseudomonas fluorescens dari beberapa Rizosfer terhadap Penyakit Virus pada Tanaman Cabai (Capsicum annum L.) di Lapangan. [Tesis]. Program Studi Agroekoteknologi Pasca Sarjana Fakultas Pertanian
Universitas Sumatera Utara Medan.

Prayudi B. 2010. Budidaya dan Pasca Panen Cabai Merah (Capsicum annum L.). Badan Penelitian dan Pengembangan Pertanian, Balai Pengkajian Teknologi Pertanian, Jawa Tengah

Pujisiswanto, Hidayat $\mathrm{P} \&$ Darwin. 2008. Pengaruh Dosis Kompos Pupuk Kandang Sapi terhadap Pertumbuhan dan Produksi Buah Tomat. Prosiding Seminar Nasional Sains dan Teknologi-II 2008. Universitas Lampung

Rosidah S, Syukur M \& Widodo. 2014. Pendugaan Parameter Genetika Ketahanan Tanaman Cabai terhadap Penyakit Antraknosa. $J$ Fitopatologi Indones 10(6): 202209.

Soedradjad R \& Avivi S. 2005. Efek Aplikasi Synechococcus sp pada Daun dan Pupuk NPK terhadap Parameter Agronomis kedelai. Bulletin Agronomi Vol 33 (3):1723

Soelaiman V \& Ernawati A. 2013. Pertumbuhan dan Perkembangan Cabai Keriting (Capsicum annuum L.) secara In Vitro pada beberapa Konsentrasi BAP dan IAA. Bul. Agrohorti 1 (1) : 62 - 66

Su YH, Liu YB \& Zang XS. 2011. Auxin-Cytokinin Interaction Regulates Meristem Development. Mol. Plant. 28: 1-10.

Sundaramoorthy S, Raguchander T, Ragupathi N \& Samiyappan R. 2012. Combinatorial Effect of Endophytic and Growth Rhizobacteria Against wilt Disease of Capsicum annum L. caused by Fusarium solani. Biol Control. 60(1):59-67.

Sutariati GAK, Widodo, Sudarsono \& Ilyas S. 2006. Pengaruh Perlakuan Rizobakteri Pemacu Pertumbuhan 
Tanaman terhadap Viabilitas Benih serta Pertumbuhan Bibit Tanaman Cabai. Jurusan Budidaya Pertanian, Faperta Universitas Haluoleo, Kendari. Bul Agro.34(1) 46-54.

Syukur M, Yulianti R, Rustam \& Widodo. 2013. Pemanfaatan Sumber Daya Genetik Lokal dalam Perakitan Varietas Unggul Cabai (Capsicum annuum L.) Tahan terhadap Penyakit Antraknosa yang Disebabkan oleh Colletotrichum sp. J Ilmu Pertanian Indonesia (JIPI). 18 (2): 67-72.

Thakuria D, Talukdar NC, Goswami C, Hazarika S \& Boro RC, 2004. Characterization and Screening of Bacteria from Rhizosphere of Rice Grown in Acidic Soils of Assam. Current Science. 86:978-985.

Tian XL, Cao LX, Tan HM, ZengQG, Jia YY, Han WQ and Zhou SN.. 2004. Study on the communities of endophytic fungi and endophytic actinomycetes from rice and their antipathogenic activities in vitro. World Journal of Microbiology and Biotechnology 20:303-309.

Yamada T. 1993. The Role of Auxin in Plant Disease Development. Ann. Rev. Phytopathol. 31: 253-257. 